\title{
Evaluation of Genetic Diversity in Gloriosa superba L, an Endangered Medicinal Plant Using Molecular Marker
}

\author{
K.S. Sahana ${ }^{1^{*}}$, R. Gnanam ${ }^{1}$, S. Rajesh ${ }^{1}$ and K. Rajamani $^{2}$ \\ ${ }^{1}$ Department of Plant Biotechnology, Tamil Nadu Agriculture University, \\ Coimbatore-641003, Tamil Nadu, India \\ ${ }^{2}$ Department of Medicinal and Aromatic Crops, Tamil Nadu Agriculture University, \\ Coimbatore-641003, Tamil Nadu, India \\ *Corresponding author
}

\section{A B S T R A C T}

\begin{tabular}{|c|c|}
\hline Keywords & $\begin{array}{l}\text { Genetic diversity evaluation among } 16 \text { Gloriosa accessions collected from different } \\
\text { locations in Tamil Nadu was studied by using Inter-simple sequence repeat (ISSR) }\end{array}$ \\
\hline $\begin{array}{l}\text { Genetic div } \\
\text { Gloriosa, In } \\
\text { simple sequ } \\
\text { repeat (ISSI } \\
\text { Cluster ana }\end{array}$ & $\begin{array}{l}\text { markers. Thirty six ISSR primers were used, among that } 16 \text { primers showed } 83.56 \text { per cent } \\
\text { polymorphism and produced } 213 \text { amplicons. This indicates that there is a high level of } \\
\text { variation at the genetic level among these accessions. The primer UBC- } 807 \text { showed the } \\
\text { highest PIC value ( } 0.958) \text {, which represented the high efficiency of the individual primer. } \\
\text { Gloriosa accessions GSU-6 and GSU-7 are highly similar with } 68 \text { per cent and GSU-7 and }\end{array}$ \\
\hline Art & \\
\hline $\begin{array}{l}\text { Accep } \\
17 \mathrm{Ma} \\
\text { Availc } \\
10 \mathrm{Jur}\end{array}$ & $\begin{array}{l}\text { Gloriosa accessions were grouped into two major clusters, of which one cluster contained } \\
\text { all } 15 \text { accessions whereas as another cluster contained GSU-16 accession alone. This } \\
\text { represents that the Gloriosa accession GSU-16 is genetically distinct from other accessions } \\
\text { based on banding pattern. }\end{array}$ \\
\hline
\end{tabular}

\section{Introduction}

Gloriosa superba $\mathrm{L}$. is one among the highly valuable medicinal and ornamental crops belongs to family Colchicaceae. Gloriosa commonly known as Glory lily, Malabar lily, and flame lily in English, Kalahari in Hindi, Visalya in Sanskrit, Kazhappaikizhang, Karthigaikizhangu, or Sengandhal malar in Tamil. It is originated from Asia and South African countries. Among Asian countries, it is grown in Bangladesh, Srilanka and India. In
India, Gloriosa is one of the major cultivated medicinal crops in Himalayan foothills, central India, Tamil Nadu, Maharashtra, Karnataka, Kerala and Goa. Tamil Nadu leads in the production and area of Gloriosa and it is also the state flower of Tamil Nadu and the national flower of Zimbabwe.

Gloriosa seeds and tubers contain alkaloids like colchicine, colchicoside, gloriosine as major constituents. Gloriosa has higher colchicine level than Colchicum plant (Finnie 
and Van Staden, 1991). There is a great demand for colchicine because of its medicinal value, which is used to treat Mediterranean fever, arthritis, rheumatism, inflammation, skin diseases, leprosy, and snake bite (Jana and Shekhawat, 2011). Colchicine also has an anti-cancerous activity that blocks the cell division of cancerous cells by inhibiting the tubulin formation so that colchicine could be used as a potential anticancerous drug (Ashok Kumar et al., 2017). During cell division, colchicine interrupt spindle fibre formation and also induces polyploidy through chromosome doubling which is used for plant breeding research and cytological studies (Kumar, 1953). Gloriosa become endangered, also in verge of extinction and included in Red data book, because of less germination percentage, poor viability of seeds, dormancy of tubers, low multiplication rate coupled with overexploitation of plants because of its medicinal value by local population and pharmaceutical companies (Yadav et al., 2012). So, there is a acute need to develop a protocol for commercial propagation and tracing the adopted variant at a genetic level for conservation of this endangered species by using biotechnological approaches (Rajagopal and Rajamani, 2013).

Gloriosa having well- adaptability to various geographical locations shows variations at both morphological and genetic level (Reddy and Lakshmi, 2016) this leads to varying chemical composition particularly alkaloid content with respect to location. Molecular markers or DNA markers are the best tools and widely used for screening the variation at the genetic level within the accessions or ecotype (Forrest et al., 2000) and also for hybridization of populations and identification of novel genes for further studies and its conservation (Jasmine and Balakrishnan, 2018). Molecular markers show high polymorphism and independent of environmental effects. RAPD and ISSR methodology has been used in many medicinal crops. ISSR markers are highly reproducible than the RAPD markers (Selvarasu and Kandhasamy, 2017). ISSR markers amplify the flanked region between the microsatellite sequences by using a single primer having repeating sequence that gives multiple amplification products. The present study attempts to assess the genetic variation among the Gloriosa accessions that are collected from different locations of Tamil Nadu by using ISSR (Inter-Simple Sequence Repeat) markers for subsequent useful exploitation in crop improvement programs.

\section{Materials and Methods}

\section{Sample collection}

Gloriosa tubers were collected from 16 different locations of Tamil Nadu as listed in Table 1 and planted in the field.

\section{DNA extraction}

Genomic DNA was extracted from leaves the samples of 16 Gloriosa accessions by following a modified CTAB method (Wilkie et al., 1997). The quality of extracted DNA was checked by 0.8 per cent Agarose gel electrophoresis in the $1 \mathrm{X}$ TBE (Tris Borate EDTA) buffer at 70 volts and the quantity was estimated by Microvolume spectrophotometer (Jenway nano). Based on the DNA concentration, the genomic DNA was further diluted to the required concentration (25-50 ng) using sterile water for subsequent use.

\section{ISSR analysis}

Genomic DNA of 16 Gloriosa accessions were amplified by ISSR markers. The amplification was done in a $20 \mu \mathrm{l}$ PCR reaction mixture containing $50 \mathrm{ng}$ of $1 \mu \mathrm{l}$ 
genomic DNA, $0.4 \mu \mathrm{l}$ of $10 \mu \mathrm{M}$ dNTPs, $1 \mu \mathrm{l}$ of $20 \mathrm{pMol}$ ISSR primer, $2.0 \mu \mathrm{l}$ of $10 \mathrm{X}$ PCR buffer with $\mathrm{MgCl}_{2}, 1$ unit of Taq polymerase enzyme (TAKARA $\mathrm{Taq}^{\mathrm{TM})}$ and $15.3 \mu \mathrm{l}$ of deionised water. The amplification was performed in a Thermal cycler (Eppendorf Master cycler nexus GX-2). Amplification started by initial denaturation at $94^{\circ} \mathrm{C}$ of 3 min. for 1 cycle, followed by denaturation for $1 \mathrm{~min}$. at $94^{\circ} \mathrm{C}$, annealing of primers at 45 $65^{\circ} \mathrm{C}$ for $1 \mathrm{~min}$. repeated above step for 40 cycles, followed by the extension of sequence at $72^{\circ} \mathrm{C}$ for $1 \mathrm{~min}$., then final extension at $72^{\circ} \mathrm{C}$ for $10 \mathrm{~min}$. The amplified ISSR markers were separated on $2.5 \%$ agarose gel and stained with Ethidium bromide. The banding pattern was visualized and documented in the gel documentation system (Gel Stan 1312).

\section{Data analysis}

Bands were scored by giving one and zero binary codes for the presence and absence of bands respectively. The data obtained from bands scoring of the ISSR profile were converted into a similarity matrix using Jaccard's coefficient. The value from the similarity matrix was subjected to cluster analysis for dendrogram construction by unweighted pair- group method using arithmetic averages (UPGMA) with the SAHN (Sequential agglomerative hierarchical and nested) function. Principal coordinate (PCO) analyses were done for a similarity coefficient to visualize the grouping of different accessions. NTSYS-pc version $2.02 \mathrm{i}$ software was used for data analysis (Rohlf, 2000).

\section{Results and Discussion}

\section{Marker polymorphism}

Gloriosa is endangered and at the verge of extinction because of its overexploitation and poor propagation. So, the information on genetic diversity of the population will be helpful for the conservation program. The external environment and geographical range directly influence or disturb the genetic distribution (Amit Kumar et al., 2014). In this study, the genetic variation among 16 Gloriosa accessions collected from various location of Tamil Nadu were analysed using the ISSR markers. Among 36 ISSR primers used, 16 primers showed polymorphism which produced 213 bands, in that 178 bands were polymorphic accounting for 83.5 per cent polymorphism across the 16 Gloriosa accessions. Among the 16 polymorphic ISSR primers, 3 ISSR primers (UBC-807, UBC-820 and UBC-821) showed 100 per cent polymorphism. The amplicons size ranged from 200 to $3000 \mathrm{bp}$. The total number of amplicons or bands produced per primer varied from 4 (BH-5) to 36 (UBC-807) with an average 13.3 amplicons per primer (Table 2). A similar result of 86.2 per cent polymorphism was obtained in five Gloriosa accessions collected from different locations of Tamil Nadu (Jasmine and Balakrishnan, 2018) and was also corroborated by Rajagopal and Rajamani (2013) with 88 per cent polymorphism from 58 RAPD primers and 60.30 per cent polymorphism from 22 ISSR primers. This result suggest that few numbers of ISSR primer were sufficient than more number of RAPD primer for genetic diversity analysis. Another medicinal plant Chlorophytum borivilanum showed 82.7 per cent polymorphism from 6 ISSR primers (Fig. $1)$.

Above results showed that Gloriosa showed higher diversity because it should have got adapted to various environments. On analysis of the polymorphic information content (PIC), 16 ISSR primers showed PIC value ranging from 0.958 to 0.710 . Primer UBC-807 showed highest PIC value represent the efficiency of the individual primer. The similar PIC value range (0.947 to 0.764$)$ for 
the primer UBC-807 with highest PIC value was also observed in five Gloriosa mutants (Selvarasu and Kandhasamy, 2017).

\section{Similarity matrix}

Based on the banding pattern obtained from 16 ISSR primers, similarity coefficient values were calculated. Similarity coefficient values ranged from 0.392 to 0.688 . The GSU-6 (Ponnivadi Local) and GSU-7 (Ponparappi
Local) were identified as identical genotypes with 68 per cent similarity followed by GSU10 (Amanakkunatham Local) and GSU-12 (Paraivalasu Local) with 65 per cent similarity. The Gloriosa accessions GSU-16 (Dharapuram local) and GSU-7 (Ponparappi Local) were distinct genotypes with 39 per cent similarity and GSU-16 accession show least similarity with all remaining 15 Gloriosa accessions as shown in Table 3.

Table.1 List of Gloriosa accessions from various geographical location of Tamil Nadu

\begin{tabular}{|c|c|c|}
\hline Sl.no & Accessions number & Name of the germplasm \\
\hline 1 & GSU-1 & Mettupalayam local \\
\hline 2 & GSU-2 & Vedaranyam local-1 \\
\hline 3 & GSU-3 & Andhra local \\
\hline 4 & GSU-4 & Ambilikkai local \\
\hline 5 & GSU-5 & Kovilpatti local \\
\hline 6 & GSU-6 & Ponnivadi local \\
\hline 7 & GSU-7 & Ponparappi local \\
\hline 8 & GSU-8 & Meenakshivalasu local \\
\hline 9 & GSU-9 & Aravakurichi local \\
\hline 10 & GSU-10 & Amanakkunatham local \\
\hline 11 & GSU-11 & Vaiyampatti local \\
\hline 12 & GSU-12 & Paraivalasu local \\
\hline 13 & GSU-13 & Kilangundal local \\
\hline 14 & GSU-14 & Sengottai local \\
\hline 15 & GSU-15 & Vedaranyam local \\
\hline 16 & GSU-16 & Dharapuram local \\
\hline
\end{tabular}


Table.2 List of primers and their amplification details

\begin{tabular}{|c|c|c|c|c|c|c|c|}
\hline Sl. no & $\begin{array}{l}\text { Primer } \\
\text { name }\end{array}$ & $\begin{array}{c}\text { Total no. } \\
\text { of } \\
\text { amplifie } \\
\text { d bands }\end{array}$ & $\begin{array}{c}\text { Number of } \\
\text { monomorphi } \\
\text { c bands }\end{array}$ & $\begin{array}{c}\text { Number of } \\
\text { polymorphi } \\
\text { c bands }\end{array}$ & $\begin{array}{c}\text { Molecular } \\
\text { weight } \\
\text { range (bp) }\end{array}$ & $\begin{array}{c}\text { PIC } \\
\text { Value }\end{array}$ & $\begin{array}{c}\text { Total } \\
\text { percentage } \\
\text { polymorphism }\end{array}$ \\
\hline $\mathbf{1}$ & 807 & 36 & 0 & 36 & $230-2250$ & 0.958 & 100.00 \\
\hline $\mathbf{2}$ & 808 & 21 & 1 & 20 & $150-1500$ & 0.930 & 95.24 \\
\hline $\mathbf{3}$ & 813 & 8 & 2 & 6 & $500-1600$ & 0.837 & 75.00 \\
\hline $\mathbf{4}$ & 815 & 18 & 1 & 17 & $320-2900$ & 0.903 & 94.44 \\
\hline $\mathbf{5}$ & 820 & 9 & 0 & 9 & $550-2000$ & 0.823 & 100.00 \\
\hline $\mathbf{6}$ & 821 & 21 & 0 & 21 & $385-2200$ & 0.928 & 100.00 \\
\hline $\mathbf{7}$ & 823 & 13 & 3 & 10 & $200-980$ & 0.879 & 76.92 \\
\hline $\mathbf{8}$ & 824 & 14 & 3 & 11 & $200-1700$ & 0.896 & 78.57 \\
\hline $\mathbf{9}$ & 827 & 8 & 1 & 7 & $810-1700$ & 0.742 & 87.50 \\
\hline $\mathbf{1 0}$ & 836 & 6 & 3 & 3 & $880-1900$ & 0.771 & 50.00 \\
\hline $\mathbf{1 1}$ & 846 & 7 & 3 & 4 & $700-1500$ & 0.789 & 57.14 \\
\hline $\mathbf{1 2}$ & 859 & 9 & 3 & 6 & $400-2800$ & 0.864 & 66.67 \\
\hline $\mathbf{1 3}$ & 868 & 16 & 6 & 10 & $320-3000$ & 0.905 & 62.50 \\
\hline $\mathbf{1 4}$ & BH-3 & 13 & 3 & 10 & $360-1600$ & 0.891 & 76.92 \\
\hline $\mathbf{1 5}$ & BH-14 & 10 & 4 & 6 & $430-1700$ & 0.886 & 60.00 \\
\hline $\mathbf{1 6}$ & BH-15 & 4 & 2 & 2 & $400-800$ & 0.710 & 50.00 \\
\hline Total & & 213 & 35 & 178 & & & \\
\hline
\end{tabular}

Table.3 Similarity matrix obtained from the banding pattern of 16 Gloriosa accessions

\begin{tabular}{|c|c|c|c|c|c|c|c|c|c|c|c|c|c|c|c|c|}
\hline & $\begin{array}{l}\text { GSU } \\
1\end{array}$ & $\begin{array}{l}\text { GSU } \\
2\end{array}$ & $\begin{array}{l}\text { GSU } \\
\mathbf{3}\end{array}$ & $\begin{array}{l}\text { GSU } \\
4\end{array}$ & $\begin{array}{l}\text { GSU } \\
5\end{array}$ & GSU6 & $\begin{array}{l}\text { GSU } \\
7\end{array}$ & GSU8 & $\begin{array}{l}\text { GSU } \\
9\end{array}$ & $\begin{array}{l}\text { GSU1 } \\
0\end{array}$ & GSU11 & GSU12 & GSU13 & GSU14 & GSU15 & GSU16 \\
\hline GSU1 & 1.000 & & & & & & & & & & & & & & & \\
\hline GSU2 & 0.612 & 1.000 & & & & & & & & & & & & & & \\
\hline GSU3 & 0.563 & 0.512 & 1.000 & & & & & & & & & & & & & \\
\hline GSU4 & 0.456 & 0.491 & 0.521 & 1.000 & & & & & & & & & & & & \\
\hline GSU5 & 0.518 & 0.518 & 0.595 & 0.448 & 1.000 & & & & & & & & & & & \\
\hline GSU6 & 0.547 & 0.560 & 0.618 & 0.520 & 0.615 & 1.000 & & & & & & & & & & \\
\hline GSU7 & 0.527 & 0.527 & 0.621 & 0.465 & 0.594 & 0.683 & 1.000 & & & & & & & & & \\
\hline GSU8 & 0.471 & 0.515 & 0.507 & 0.455 & 0.546 & 0.552 & 0.489 & 1.000 & & & & & & & & \\
\hline GSU9 & 0.480 & 0.528 & 0.572 & 0.512 & 0.538 & 0.622 & 0.560 & 0.546 & 1.000 & & & & & & & \\
\hline GSU10 & 0.492 & 0.551 & 0.606 & 0.465 & 0.547 & 0.565 & 0.580 & 0.500 & 0.535 & 1.000 & & & & & & \\
\hline GSU11 & 0.500 & 0.571 & 0.588 & 0.462 & 0.543 & 0.573 & 0.576 & 0.551 & 0.579 & 0.636 & 1.000 & & & & & \\
\hline GSU12 & 0.500 & 0.547 & 0.603 & 0.484 & 0.511 & 0.562 & 0.577 & 0.529 & 0.543 & 0.651 & 0.583 & 1.000 & & & & \\
\hline GSU13 & 0.500 & 0.513 & 0.574 & 0.522 & 0.465 & 0.584 & 0.521 & 0.496 & 0.536 & 0.533 & 0.542 & 0.569 & 1.000 & & & \\
\hline GSU14 & 0.476 & 0.487 & 0.596 & 0.459 & 0.523 & 0.592 & 0.508 & 0.508 & 0.508 & 0.568 & 0.551 & 0.577 & 0.604 & 1.000 & & \\
\hline GSU15 & 0.464 & 0.475 & 0.543 & 0.495 & 0.478 & 0.580 & 0.520 & 0.508 & 0.508 & 0.532 & 0.552 & 0.553 & 0.546 & 0.627 & 1.000 & \\
\hline GSU16 & 0.459 & 0.471 & 0.475 & 0.441 & 0.410 & 0.476 & 0.393 & 0.416 & 0.467 & 0.415 & 0.444 & 0.500 & 0.460 & 0.500 & 0.568 & 1.000 \\
\hline
\end{tabular}


Fig.1 Amplification profile of 16 Gloriosa accessions by ISSR primers UBC-807(a), UBC 808(b), UBC 827(c) and UBC 821(d). M represent 100 bp DNA ladder. Number 1-16 shows 16 Gloriosa accessions
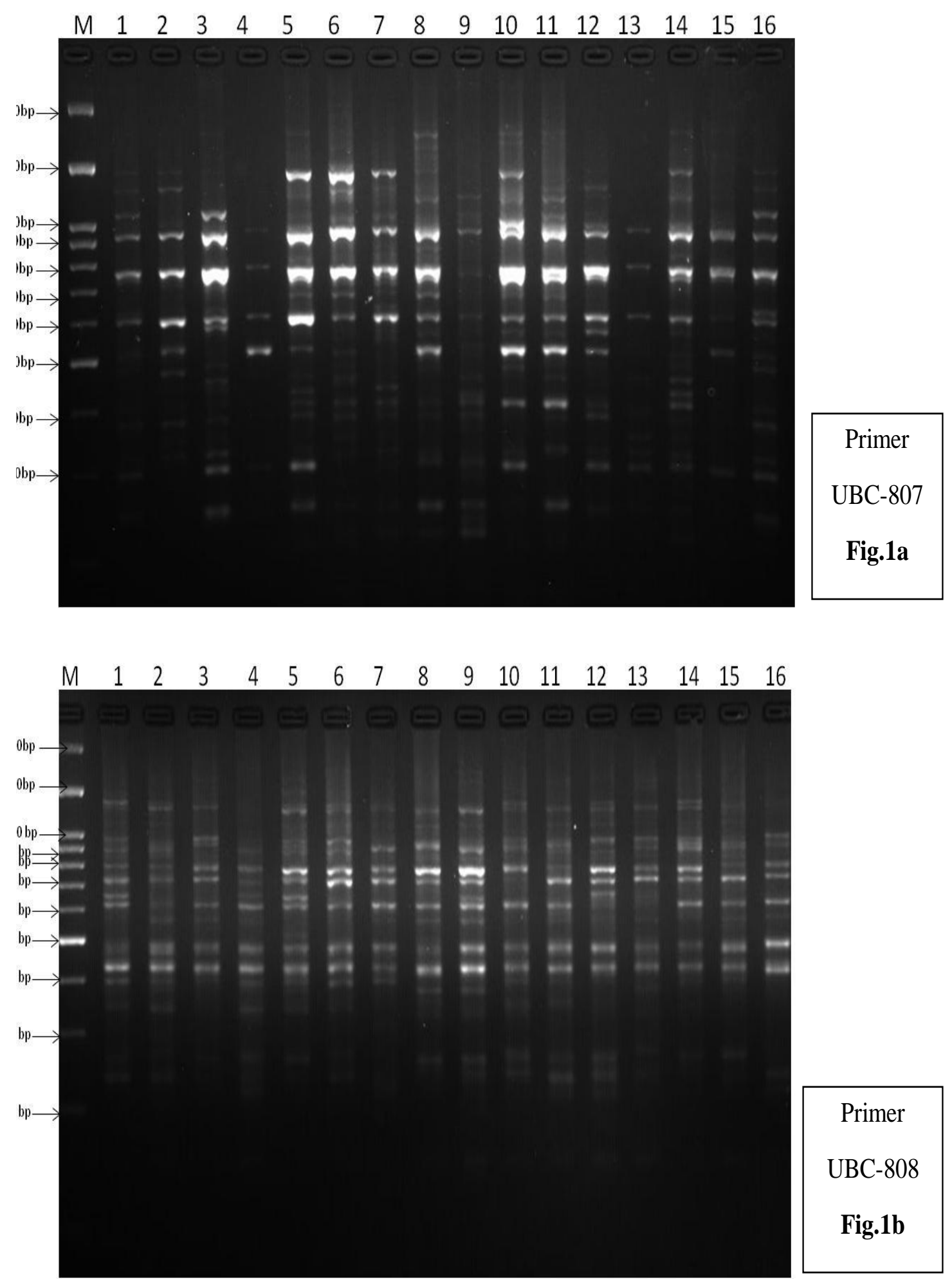

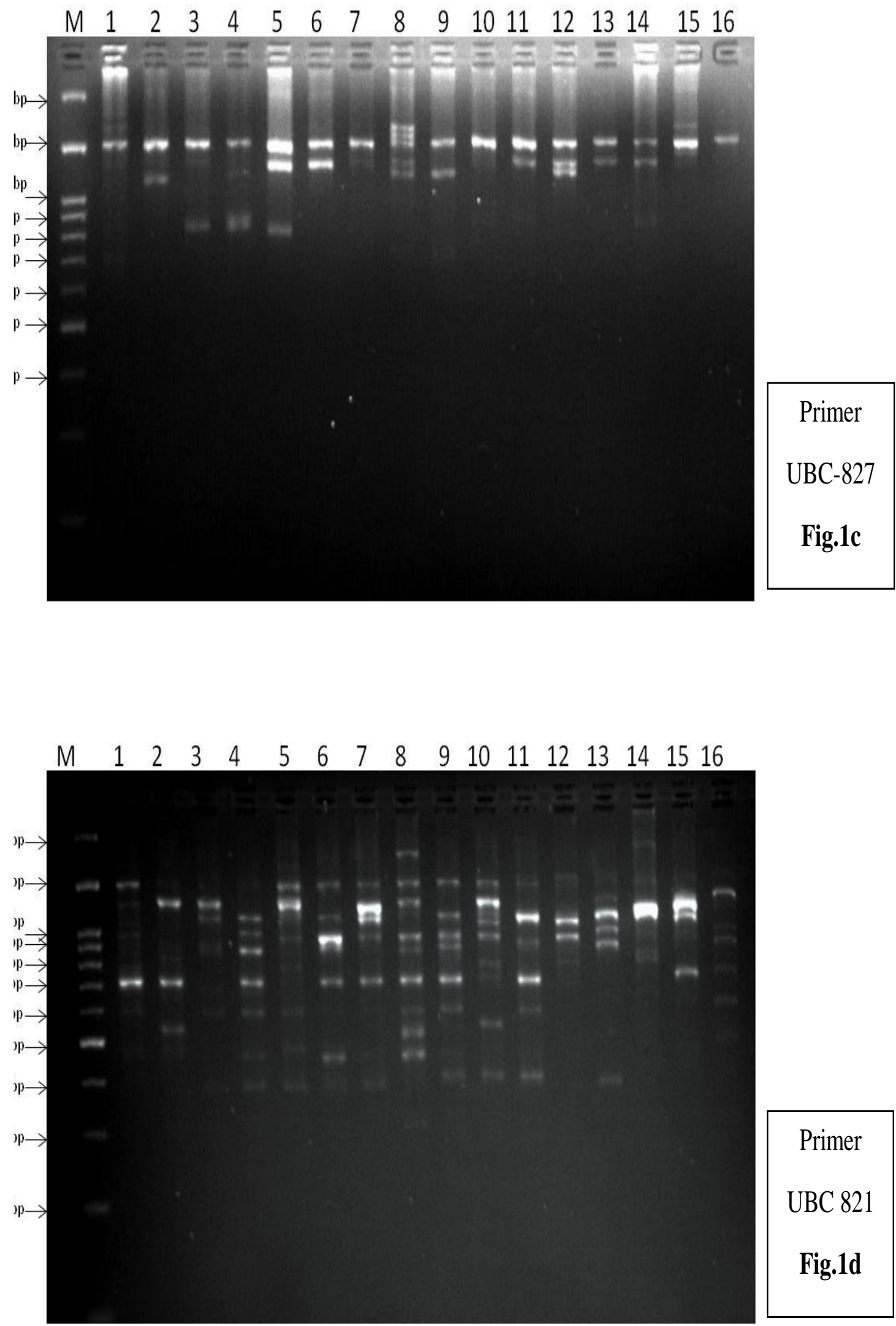
Fig.2 Dendrogram showing the clustering pattern of 16 Gloriosa accessions based on similarity value obtained from ISSR primer. (GSU1-GSU16) represented the Gloriosa accessions

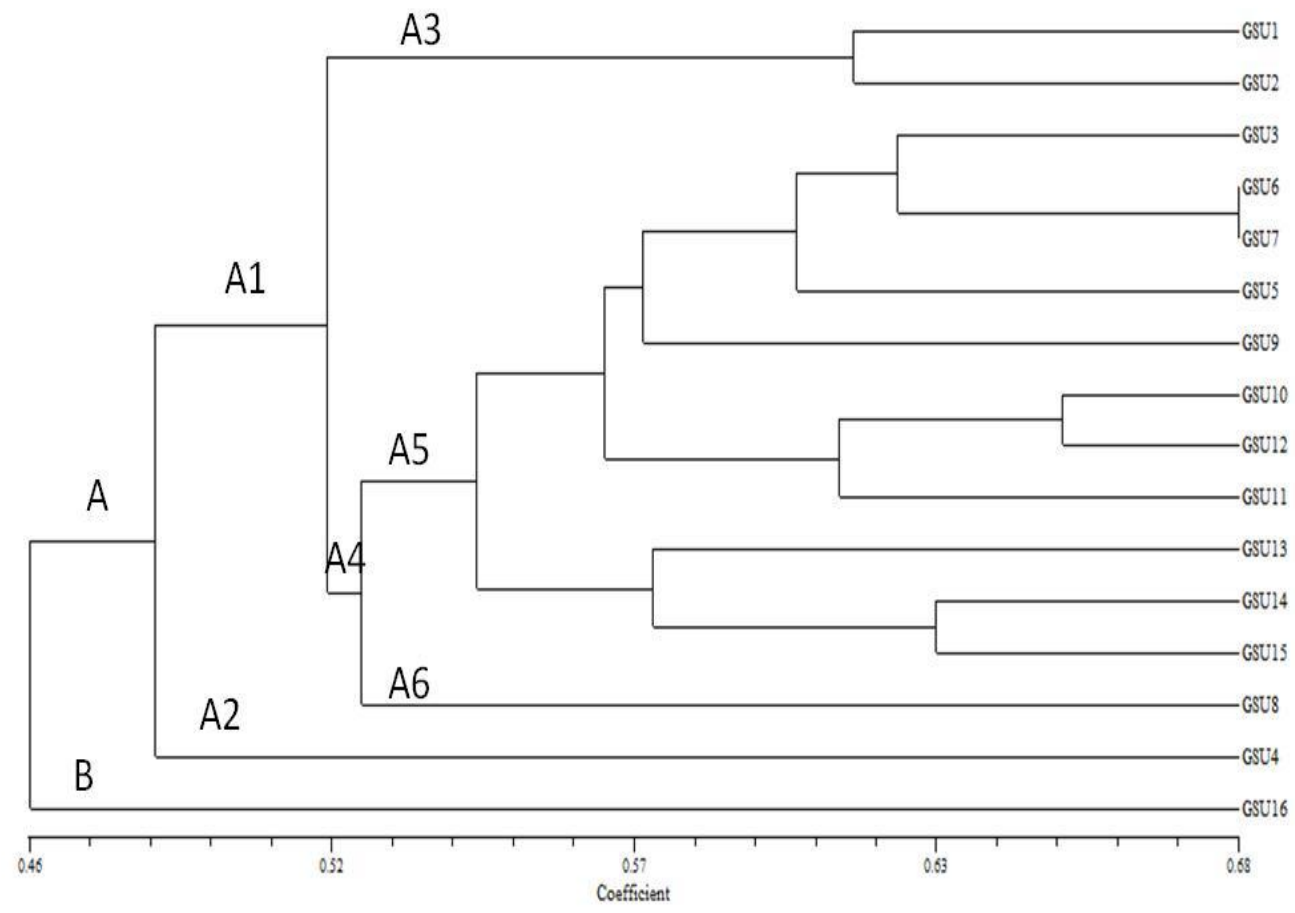

Fig.3 Principal coordinate analysis (PCA) and grouping pattern of 16 Gloriosa accessions

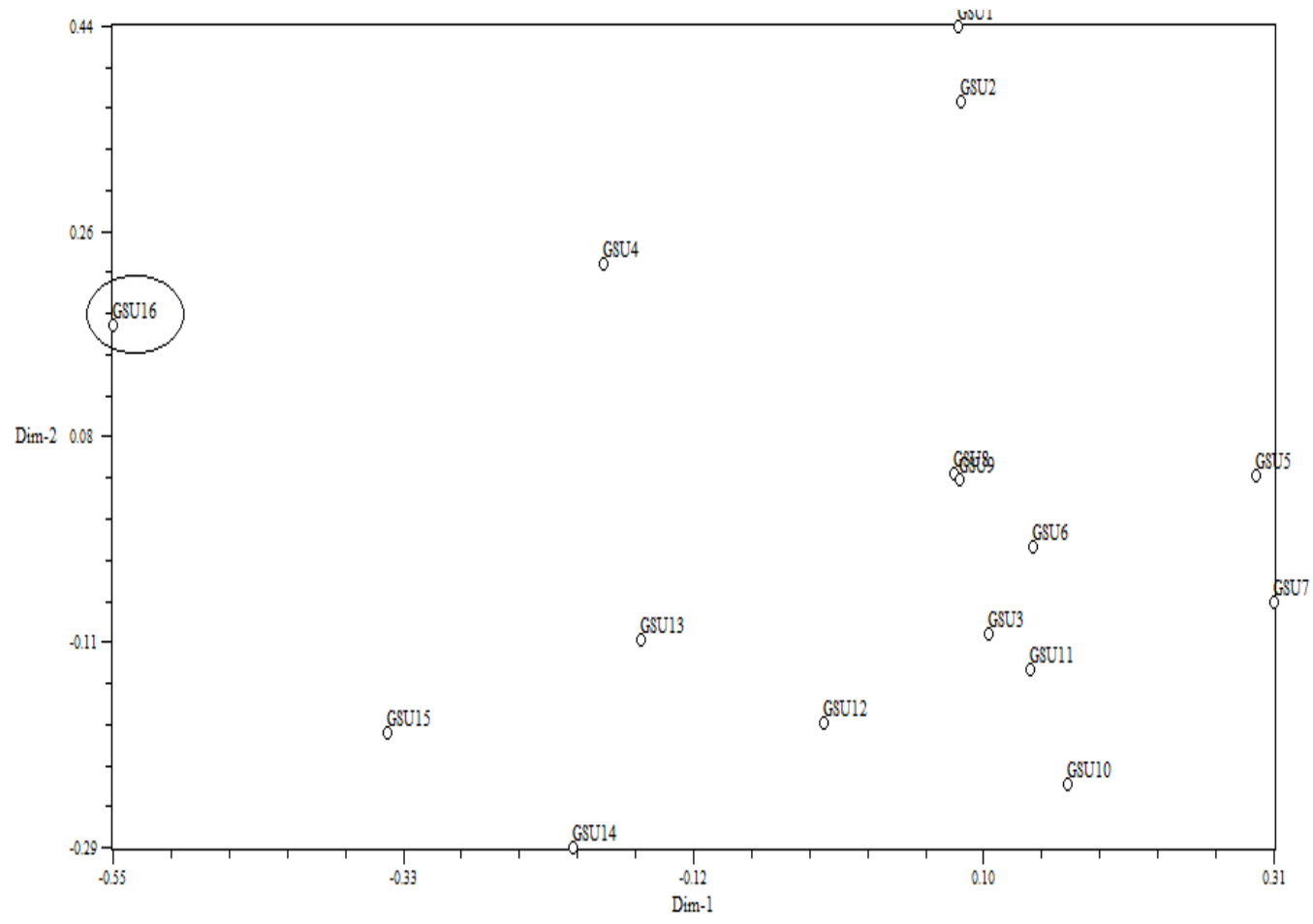




\section{Cluster analysis}

A dendrogram was constructed based on the similarity coefficient value of the 16 Gloriosa accessions that grouped into two major groups A and B. Group A comprises of all 15 accessions and Group B comprises GSU-16 (Dharapuram local) alone. Group A was sub grouped into A1 and A2, subgroup A2 has single accession GSU-4 (Ambilikkai local) as shown in Figure 2. This distinct accession can be further used for crossing or breeding studies and conservation. Principal coordinate analysis based on the similarity value of 16 Gloriosa accessions clearly distinguished the accessions into groups similar to the result of cluster analysis. 2D image represent the grouping pattern among accessions in Figure 3.

\section{Acknowledgements}

Authors are thankful to Department of Plant Biotechnology, Tamil Nadu Agricultural University, Coimbatore for providing the facilities to carry out this research work. The financial assistance from DBT for carrying out this research is greatly acknowledged.

\section{References}

Finnie, J., and Van Staden, J. (1991). Isolation of colchicine from Sandersonia aurantiaca and Gloriosa superba. Variation in the alkaloid levels of plants grown in vivo. Journal of plant physiology, 138(6), 691-695.

Forrest, I., Burg, K., and Klumpp, R. (2000). Genetic markers: tools for identifying and characterising Scots pine populations. Forest Systems, 9(S1), 6788.

Jana, S., and Shekhawat, G. (2011). Critical review on medicinally potent plant species: Gloriosa superba. Fitoterapia, 82(3), 293-301.
Jasmine, J. P., and Balakrishnan, V. (2018). Intra specific analysis of Gloriosa superba (L) through issr finger printing and dna sequencing of ecotypes collected from different accessions of Tamil Nadu State, India. Research in Plant Biology, 17-21.

Kumar, A., Mishra, P., Singh, S. C., and Sundaresan, V. (2014). Efficiency of ISSR and RAPD markers in genetic divergence analysis and conservation management of Justicia adhatoda L., a medicinal plant. Plant systematics and evolution, 300(6), 1409-1420.

Kumar, A., Sharma, P. R., and Mondhe, D. M. (2017). Potential anticancer role of colchicine-based derivatives: an overview. Anti-cancer drugs, 28(3), 250-262.

Kumar, L. (1953). Doubling of Chromosomes induced by Gloriosine isolated from Gloriosa superba, Linn. Nature, 171(4357), 791.

Rajagopal, C., and Rajamani, K. (2013). Assessment of genetic diversity of Gloriosa superba L. accessions detected by random amplified polymorphic DNA analysis. Journal of Medicinal Plants Research, 7(28), 2122-2127.

Reddy, M. P., Sarla, N., and Siddiq, E. (2002). Inter simple sequence repeat (ISSR) polymorphism and its application in plant breeding. euphytica, 128(1), 9-17.

Reddy, S., and Lakshmi, J. N. (2016). DNA isolation from tubers and molecular characterization in Gloriosa superba $L$.

Rohlf, F. (2000). Numerical taxonomy and multivariate analysis system NTSYS-pc version2. 1 user guide. New York: Exeter Software Setauket.

Selvarasu, A., and Kandhasamy, R. (2017). Molecular and Agro-Morphological Genetic Diversity Assessment of Gloriosa superba Mutants. European Journal of Medicinal Plants, 1-13. 
Siddique, N., Bari, M., Pervin, M., Nahar, N.,

Plant Molecular Biology-A Banu, L., Paul, K., Ferdaus, K. (2005). Screening of Endangered Medicinal Plants Species by Questionnaire Survey in Barind Tract in Bangladesh. Pak. J. Biol. Sci, 8(12), 1783-1793.

Tian, H.-L., Xue, J.-H., Wen, J., Mitchell, G., and Zhou, S.-L. (2008). Genetic diversity and relationships of lotus (Nelumbo) cultivars based on allozyme and ISSR markers. Scientia Horticulturae, 116(4), 421-429.

Wilkie, S., Clark, M., Leroy, P., Merlino, M., Nègre, S., Caissard, J., Bernard, M. (1997). Genomic DNA isolation, Laboratory Manual (pp. 3-53): Springer.

Wolfe, A. D., and Liston, A. (1998). Contributions of PCR-based methods to plant systematics and evolutionary biology Molecular systematics of plants II (pp. 43-86): Springer.

Yadav, K., Aggarwal, A., and Singh, N. (2012). Actions for ex situ conservation of Gloriosa superba L.-an endangered ornamental cum medicinal plant. Journal of Crop Science and Biotechnology, 15(4), 297-303.

\section{How to cite this article:}

Sahana, K.S., R. Gnanam, S. Rajesh and Rajamani, K. 2019. Evaluation of Genetic Diversity in Gloriosa superba L, an Endangered Medicinal Plant Using Molecular Marker. Int.J.Curr.Microbiol.App.Sci. 8(06): 2125-2134. doi: https://doi.org/10.20546/ijcmas.2019.806.252 